\title{
Impact of manure and organic fertilizers on the quantity and content yield of heavy metals in spring rape
}

\author{
Edward Krzywy, Anna Iżewska \\ University of Agriculture, Department of Environmental Chemistry, ul. J. Stowackiego 17, 71-434 Szczecin, Poland, \\ e-mail: izewska@agro.ar.szczecin.pl
}

\begin{abstract}
The pot experiment was set up with the split plot method in three repetitions in 2006. The objects of the first factor were the doses of manure and organic fertilizers to the soil in conversion to the brought in nitrogen ( 85 and $170 \mathrm{~kg} \mathrm{~N} \cdot h \mathrm{a}^{-1}$ ), the objects of the second factor were the types of fertilizers: manure, sewage sludge and the composts prepared from sewage sludge. The soil used in an experiment was supplied from The Agricultural Experimental Station in Lipnik. The soil was taken from the arable layer, it has the granulometric composition of the light loamy sand.

The content of available phosphorus, potassium and magnesium formed on medium level, the $\mathrm{pH}_{\mathrm{KC}}$ of the soil amounted to 5.13 . The soil was characterized by $0^{\circ}$ contamination of trace elements, which means that it contained the natural content of cadmium, copper, nickel, lead and zinc. Spring rape var. Licosmos was the test plant.

The aim of the research was the assessment of the influence of manure, sewage sludge and compost prepared from sewage sludge on yield quantity of seeds and straw and the content of cadmium, nickel, lead and zinc in spring rape.

The conducted research shows that fertilizers brought into the soil (manure, sewage sludge and compost prepared from sewage sludge) as well as two levels of fertilizing had a significant influence on the yield of the seeds and straw of spring rape. Manure, sewage sludge and compost prepared from sewage sludge played less significant influence on the decreasing or excessive increasing of heavy metals concentration in the seeds of spring rape. The double dose of fertilizers caused higher accumulation of heavy metals in the test plant. The straw of spring rape should be treated as a source of organic matter and the main nutrients for the soil. The highest concentration of copper, manganese, nickel and zinc in the straw of spring rape was noticed after the application of sewage sludge and of cadmium and lead after the application of compost prepared from sewage sludge.
\end{abstract}

Keywords: manure, sewage sludge, compost prepared from sewage sludge, spring rape, heavy metals.

Presented at VII Conference Wasteless Technologies and Waste Management in Chemical Industry and Agriculture, Międzyzdroje, 12 - 15 June, 2007.

\section{INTRODUCTION}

A huge decline in the population of farm animals, which took place in Poland in recent years, caused limitation in the production of natural fertilizers including manure. For the reason of limited application of natural fertilizers, the content of organic substance and humus in the soil has decreased. In consequence it has led to the reduction of soils' fertility. In connection with this situation a research for other solutions was started, the purpose of which was an improvement of the negative balance of the organic substance and the nutrients in the soil through the application of sewage sludge and composts prepared from sewage sludge. The possibility of the agricultural usage of sewage sludge and composts prepared from sewage sludge is decided on basis of the content of heavy metals in it ${ }^{1}$.

The aim of the research was to estimate the influence of applying sewage sludge and composts prepared from sewage sludge on the crop quantity of the seed and straw and also on the content of cadmium, nickel, lead and zinc in spring rape.

\section{MATERIALS AND METHODS}

The pot experiment was set up with the split plot method in three repetitions in 2006. The objects of the first factor were the doses of manure and organic fertilizers to the soil in conversion to the brought in nitrogen (85 and 170 $\mathrm{kg} \mathrm{N} \cdot \mathrm{ha}^{-1}$ ), the objects of the second factor were the types of fertilizers: manure, sewage sludge and composts prepared from sewage sludge. The soil used in the experiment was taken from The Agricultural Experimental Station in Lipnik. The soil was taken from the arable layer, it has the granulometric composition of the light loamy sand.

The content of available phosphorus, potassium and magnesium formed on the medium level, the $\mathrm{pHKCl}$ of the soil amounted to 5.13. The soil was characterized by $0^{0}$ contamination of trace elements, which means that it contained the natural content of cadmium, copper, nickel, lead and zinc. The test plant was spring rape var. Licosmos.

\section{RESULTS AND DISCUSSION}

An average yield of spring rape seeds amounted to 11.66 $\mathrm{g}$ from the pot and $10.92 \mathrm{~g}$ from the control variant. The data juxtaposed in Table 1 shows that in 2006, when the direct influence of manure, organic fertilizers and NPK on the quantity yield of spring rape seeds and straw was assessed, the highest mean yield of the seeds was obtained after an application of sewage sludge ( $13.76 \mathrm{~g}$ from pot) and it was significantly higher than the yields from other fertilizing variants. 
Table 1. The yield of the seeds and straw of spring rape ( $\mathrm{g}$ from the pot)

\begin{tabular}{|c|c|c|c|c|c|c|}
\hline Dose of & & Seeds & & & Straw & \\
\hline $\begin{array}{l}\text { Type of the } \\
\text { fertilizer }\end{array}$ & I dose & II dose & mean & I dose & II dose & mean \\
\hline Manure & 10.07 & 11.32 & 10.70 & 20.37 & 23.20 & 21.78 \\
\hline Sewage sludge & 12.32 & 15.20 & 13.76 & 23.88 & 31.67 & 27.78 \\
\hline Compost & 10.89 & 11.63 & 11.26 & 22.47 & 24.51 & 23.49 \\
\hline NPK & 11.68 & 10.16 & 10.92 & 23.62 & 23.66 & 23.64 \\
\hline Mean & 11.24 & 12.08 & 11.66 & 22.58 & 25.76 & 24.17 \\
\hline Control & 11.68 & 10.16 & 10.92 & 23.62 & 23.66 & 23.64 \\
\hline
\end{tabular}

$\mathrm{LSD}_{0,05}$ for seed I factor 1.39; II factor 0.73 ; Ix|| 1.45

$\mathrm{LSD}_{0,05}$ for seed I factor 1.47 ; II factor 0.77 ; IxII 1.54

While analysing the second experimental factor it was stated that the yield of spring rape seeds was higher along with increasing the dose of fertilizers.

Statistical analyses showed a significant co-operation of experimental factors in shaping of the quantity yield of spring rape straw. The compost prepared from sewage sludge as well as mineral fertilization had similar a effect (23.49 and $23.64 \mathrm{~g}$ from the pot) but significantly better than manure. The highest yield was obtained from the object with sewage sludge and it amounted to $27.78 \mathrm{~g}$ from the pot.

While analysing the average yields of spring rape seeds and straw it could be stated that sewage sludge and compost prepared from sewage sludge gave clearly higher yields in relation to the variants fertilized with manure and fertilized with NPK.

These results confirm the research of many authors ${ }^{2,3,4}$.

The content of heavy metals in the seeds of spring rape is presented in Table 2. The average content of cadmium on the objects fertilized with manure and with organic fertilizers amounted to $0.172 \mathrm{mg} \cdot \mathrm{kg}^{-1} \mathrm{~d} . \mathrm{m}$. and on the control object $0.123 \mathrm{mg} \cdot \mathrm{kg}^{-1} \mathrm{~d}$ d.m. After the application of the second dose of the fertilizer, the content of cadmium in the seeds of spring rape grew by about $17.0 \%$.

The experimental factors did not have a significant influence on the content of copper in the seeds of spring rape. The highest content of copper in the seeds of spring rape occurred on the objects fertilized with mineral fertilizers $\left(4.18 \mathrm{mg} \cdot \mathrm{kg}^{-1} \mathrm{~d} . \mathrm{m}\right.$.) and the lowest occurred on the objects fertilized with compost prepared from sewage sludge (3.48 $\mathrm{mg} \cdot \mathrm{kg}^{-1}$ d.m.).

The concentration of manganese in the control variant in the spring rape seeds amounted to $43.7 \mathrm{mg} \cdot \mathrm{kg}^{-1} \mathrm{~d} . \mathrm{m}$. However, in the fertilizing variants it was $15.1 \%$ higher. Considering the doses of fertilizers it was stated that after the application of a higher dose, the content of manganese decreased in comparison with the lower dose.

According to Table 2 a significant impact of fertilizers on the content of nickel in the seeds of spring rape was identified. Under the influence of NPK and sewage sludge the concentration of nickel significantly increased in comparison with the objects fertilized with manure and compost prepared from sewage sludge.

The second factor, i.e. the increasing doses of fertilizers, did not have a significant influence on the content of nickel in the seeds of spring rape. However, it was observed that for the version with the higher dose, the content of nickel was $1.5 \%$ higher in comparison with the lower dose.
The average content of lead in the seeds of spring rape from the objects fertilized with manure, organic fertilizers and NPK amounted to $4,48 \mathrm{mg} \cdot \mathrm{kg}^{-1} \mathrm{~d} . \mathrm{m}$. and was 1.22 $\mathrm{mg} \cdot \mathrm{kg}^{-1}$ higher in comparison with the control object.

The seeds from the objects fertilized with mineral fertilizers showed the highest concentration of lead (5.17 $\mathrm{mg} \cdot \mathrm{kg}^{-1} \mathrm{~d}$.m.) and the lowest content of lead was noted in the seeds from the objects fertilized with the compost prepared from sewage sludge $\left(3.82 \mathrm{mg} \cdot \mathrm{kg}^{-1} \mathrm{~d} . \mathrm{m}.\right)$, however, these values were not statistically proved.

The experimental factors, i.e. the types of fertilizers and increasing the doses, did not have a significant impact on the content of zinc in the seeds of spring rape.

The lowest content of zinc occurred on the object fertilized with the second dose of manure $\left(27.7 \mathrm{mg} \cdot \mathrm{kg}^{-1} \mathrm{~d} . \mathrm{m}\right.$.) and the highest content occurred after the application of the second dose of sewage sludge (48.1 mg $\mathrm{kg}^{-1}$ d.m.).

An average increase of the content of zinc in the seeds of spring rape under the influence of the second dose of the applied fertilizers amounted to $18.1 \%$.

While analysing the data from Table 3 , the significant impact of the types of fertilizers on the content of cadmium in the straw of spring rape was stated, however, increasing the doses of fertilizers had no significant impact on this content. The highest average concentration of cadmium occurred on the objects fertilized with the compost prepared from sewage sludge and it amounted to $1.495 \mathrm{mg} \cdot \mathrm{kg}^{-1} \mathrm{~d}$.m. and was significantly higher in comparison with the objects fertilized with manure and sewage sludge. Comparing the second experimental factor, it was assessed that after the application of the second dose, the content of cadmium in the straw was $6.61 \%$ lower in comparison with the objects fertilized with the first dose.

The experimental factors did not have as significant impact on the content of copper, manganese, nickel and zinc in the straw of the test plant.

The content of copper on the control object amounted to $3.34 \mathrm{mg} \cdot \mathrm{kg}^{-1} \mathrm{~d} . \mathrm{m}$. and was on average $25.4 \%$ lower in comparison with the objects fertilized with manure, sewage sludge, compost prepared from sewage sludge and NPK.

The lowest content of copper in the straw of spring rape was noticed on the variant fertilized with the second dose of mineral fertilizers $\left(3.50 \mathrm{mg} \cdot \mathrm{kg}^{-1} \mathrm{~d} . \mathrm{m}\right.$.) and the highest on the variant fertilized with the first dose of sewage sludge ( $6.00 \mathrm{mg} \cdot \mathrm{kg}^{-1} \mathrm{~d} . \mathrm{m}$.).

The straw of spring rape from the objects fertilized with manure contained on average $30.6 \mathrm{mg} \cdot \mathrm{kg}^{-1} \mathrm{~d}$.m.manganese and after an application of sewage sludge, the quantity of 
Table 2. The content of heavy metals in the seeds of spring rape $\left(\mathrm{mg} \cdot \mathrm{kg}^{-1}\right)$

\begin{tabular}{|c|c|c|c|c|c|c|c|c|c|c|c|c|c|c|c|c|c|c|}
\hline Dose of & \multicolumn{3}{|c|}{$\mathrm{Cd}$} & \multicolumn{3}{|c|}{$\mathrm{Cu}$} & \multicolumn{3}{|c|}{$\mathrm{Mn}$} & \multicolumn{3}{|c|}{$\mathrm{Ni}$} & \multicolumn{3}{|c|}{$\mathrm{Pb}$} & \multicolumn{3}{|c|}{$\mathrm{Zn}$} \\
\hline $\begin{array}{l}\text { Types of } \\
\text { fertilizers }\end{array}$ & $1^{*}$ & $2^{*}$ & $x$ & $1^{*}$ & $2^{*}$ & $\mathrm{x}$ & $1^{*}$ & $2^{*}$ & $x$ & $1^{*}$ & $2^{*}$ & $x$ & $1^{*}$ & $2^{*}$ & $x$ & $1^{*}$ & $2^{*}$ & $\mathrm{x}$ \\
\hline Manure & 0.142 & 0.188 & 0.165 & 3.62 & 3.95 & 3.78 & 53.3 & 51.5 & 52.4 & 2.72 & 3.09 & 2.90 & 4.29 & 4.25 & 4.27 & 28.1 & 27.7 & 27.9 \\
\hline \begin{tabular}{|l|} 
Sewage sludge \\
\end{tabular} & 0.132 & 0.128 & 0.130 & 3.82 & 4.38 & 4.10 & 49.5 & 49.8 & 49.6 & 3.86 & 3.99 & 3.76 & 4.70 & 4.66 & 4.68 & 35.7 & 48.1 & 41.9 \\
\hline Compost & 0.198 & 0.230 & 0.214 & 2.78 & 4.18 & 3.48 & 56.8 & 41.3 & 49.0 & 2.86 & 2.58 & 2.72 & 3.33 & 4.31 & 3.82 & 31.4 & 32.2 & 31.8 \\
\hline NPK & 0.162 & 0.198 & 0.180 & 4.22 & 4.15 & 4.18 & 45.6 & 55.0 & 50.3 & 3.63 & 3.94 & 3.78 & 5.08 & 5.26 & 5.17 & 28.6 & 37.8 & 33.2 \\
\hline Mean & 0.159 & 0.186 & 0.172 & 3.61 & 4.16 & 3.89 & \begin{tabular}{|l|}
51.3 \\
\end{tabular} & 49.4 & 50.3 & 3.27 & 3.32 & 3.29 & 4.35 & 4.62 & 4.48 & 30.9 & 36.5 & 33.7 \\
\hline Control & & 0.123 & & & 3.60 & & & 43.7 & & & 2.27 & & & 3.26 & & & 24.1 & \\
\hline $\begin{array}{l}\text { LSD }_{0,05} \\
\text { I factor } \\
\text { II factor } \\
\text { |x|| }\end{array}$ & & $\begin{array}{l}\text { n.s. } \\
\text { n.s. } \\
\text { n.s. }\end{array}$ & & & $\begin{array}{l}\text { n.s. } \\
\text { n.s. } \\
\text { n.s. }\end{array}$ & & & $\begin{array}{l}\text { n.s. } \\
\text { n.s. } \\
\text { n.s. }\end{array}$ & & & $\begin{array}{l}1.17 \\
\text { n.s. } \\
\text { n.s. }\end{array}$ & & & $\begin{array}{l}\text { n.s. } \\
\text { n.s. } \\
\text { n.s. }\end{array}$ & & & $\begin{array}{l}\text { n.s. } \\
\text { n.s. } \\
\text { n.s. }\end{array}$ & \\
\hline
\end{tabular}

$1^{*}$ - dose I; $2^{*}$ - dose II

Table 3. The content of heavy metals in the straw of spring rape $\left(\mathrm{mg} \cdot \mathrm{kg}^{-1}\right)$

\begin{tabular}{|c|c|c|c|c|c|c|c|c|c|c|c|c|c|c|c|c|c|c|}
\hline Dose of & \multicolumn{3}{|c|}{$\mathrm{Cd}$} & \multicolumn{3}{|c|}{$\mathrm{Cu}$} & \multicolumn{3}{|c|}{$\mathrm{Mn}$} & \multicolumn{3}{|c|}{$\mathrm{Ni}$} & \multicolumn{3}{|c|}{$\mathrm{Pb}$} & \multicolumn{3}{|c|}{$\mathrm{Zn}$} \\
\hline $\begin{array}{l}\text { Types of } \\
\text { fertilizers }\end{array}$ & $1^{*}$ & $2^{*}$ & $x$ & $1^{*}$ & $2^{*}$ & $\mathrm{x}$ & $1^{*}$ & $2^{*}$ & $\mathrm{x}$ & $1^{*}$ & $2^{*}$ & $\mathrm{x}$ & $1^{*}$ & $2^{*}$ & $x$ & $1^{*}$ & $2^{*}$ & $\mathrm{x}$ \\
\hline Manure & 0.672 & 0.618 & 0.645 & 3.98 & 3.65 & 3.82 & 28.3 & 32.8 & 30.6 & 1.15 & 1.20 & 1.18 & 3.81 & 3.98 & 3.90 & 3.45 & 4.80 & 4.12 \\
\hline Sewage sludge & 0.840 & \begin{tabular}{|l|}
0.582 \\
\end{tabular} & 0.711 & 6.00 & 3.92 & 4.96 & 47.9 & 42.8 & 45.4 & 1.76 & 2.67 & 2.22 & 4.53 & 4.65 & 4.59 & 9.50 & 12.10 & 10.80 \\
\hline Compost & 1.438 & 1.552 & 1.495 & 4.25 & 4.25 & 4.25 & 34.2 & 34.6 & 34.4 & 1.50 & 1.54 & 1.52 & 5.27 & 5.30 & 5.28 & 2.80 & 5.35 & 4.08 \\
\hline NPK & 0.680 & \begin{tabular}{|l|}
0.640 \\
\end{tabular} & 0.660 & 4.00 & 3.50 & 3.75 & 37.2 & 34.6 & 35.9 & 1.34 & 1.28 & 1.31 & 4.32 & 4.92 & 4.62 & 4.30 & 3.45 & 3.88 \\
\hline Mean & 0.908 & \begin{tabular}{|l|}
0.848 \\
\end{tabular} & 0.878 & 4.56 & 3.83 & 4.19 & 36.9 & 36.2 & 36.6 & 1.44 & 1.67 & 1.56 & 4.48 & 4.71 & 4.60 & 5.01 & 6.42 & 5.72 \\
\hline Control & \multicolumn{3}{|c|}{0.627} & \multicolumn{3}{|c|}{3.34} & \multicolumn{3}{|c|}{24.3} & \multicolumn{3}{|c|}{1.02} & \multicolumn{3}{|c|}{3.67} & \multicolumn{3}{|c|}{3.20} \\
\hline $\begin{array}{l}\text { LSD }_{0,05} \\
\text { I factor } \\
\text { II factor } \\
\text { IxII }\end{array}$ & \multicolumn{3}{|c|}{$\begin{array}{l}0.57 \\
\text { n.s. } \\
\text { n.s. }\end{array}$} & \multicolumn{3}{|c|}{$\begin{array}{l}\text { n.s. } \\
\text { n.s. } \\
\text { n.s. }\end{array}$} & \multicolumn{3}{|c|}{$\begin{array}{l}\text { n.s. } \\
\text { n.s. } \\
\text { n.s. }\end{array}$} & \multicolumn{3}{|c|}{$\begin{array}{l}\text { n.s. } \\
\text { n.s. } \\
\text { n.s. }\end{array}$} & \multicolumn{3}{|c|}{$\begin{array}{l}1.25 \\
\text { n.s. } \\
\text { n.s. }\end{array}$} & \multicolumn{3}{|c|}{$\begin{array}{l}\text { n.s. } \\
\text { n.s. } \\
\text { n.s. }\end{array}$} \\
\hline
\end{tabular}

1 * dose I; $2^{*}$ - dose II

this element increased by $14.8 \mathrm{mg} \cdot \mathrm{kg}^{-1} \mathrm{~d} . \mathrm{m}$., after an application of compost by $3.8 \mathrm{mg} \cdot \mathrm{kg}^{-1} \mathrm{~d} . \mathrm{m}$. and after NPK application by $5.3 \mathrm{mg} \cdot \mathrm{kg}^{-1} \mathrm{~d} . \mathrm{m}$. The concentration of manganese in the straw of the test plant between the doses was on a similar level (36.9 and $36.2 \mathrm{mg} \cdot \mathrm{kg}^{-1} \mathrm{~d}$.m.).

According to Table 3, on the control object the content of nickel in the straw of spring rape amounted to 1.02 $\mathrm{mg} \cdot \mathrm{kg}^{-1} \mathrm{~d}$.m. and was $117.6 \%$ lower in comparison with the objects fertilized with sewage sludge. The lowest concentration of nickel in the straw of the test plant occurred after an application of the first dose of manure $1.15 \mathrm{mg} \cdot \mathrm{kg}^{-1}$ d.m. and the highest after an application of the second dose of sewage sludge $2.67 \mathrm{mg} \cdot \mathrm{kg}^{-1} \mathrm{~d} . \mathrm{m}$.

A significant decrease of the content of lead in the straw of spring rape ensued after an application of manure. This content $\left(3.90 \mathrm{mg} \cdot \mathrm{kg}^{-1} \mathrm{~d} . \mathrm{m}\right.$.) was significantly lower in comparison with the objects fertilized with the compost prepared from sewage sludge $\left(5.28 \mathrm{mg} \cdot \mathrm{kg}^{-1} \mathrm{~d} . \mathrm{m}\right.$.). After an application of the double dose of fertilizers an increase of the average content of lead occurred in comparison with the single dose by $4.88 \%$.

The content of zinc in the straw of spring rape on the control object amounted to $3.20 \mathrm{mg} \cdot \mathrm{kg}^{-1} \mathrm{~d} . \mathrm{m}$. (tab. 3 ) and was $28.8 \%$ lower in comparison with the objects fertilized with manure, $237.5 \%$ lower in comparison with the objects fertilized with sewage sludge, $27.5 \%$ lower in comparison with the objects fertilized with compost prepared from sewage sludge and $21.2 \%$ lower in comparison with the objects fertilized with NPK.

The analyses that were carried out showed that the content of heavy metals in the plant material did not exceed permissible norms (with the exception of cadmium and lead) of usefulness of the product for consumption ${ }^{5}$ as well as for fodder and for industry ${ }^{6}$.
The simitation of bioavailability of heavy metals from sewage sludge and compost prepared from sewage sludge by spring rape could have been influenced by organic matter, which was brought along with sewage sludge and compost and created stable organometallic connections ${ }^{7,8}$.

Different investigations ${ }^{\mathbf{9}} \mathbf{1 0}$ showed that heavier metals accumulated in the roots than in the above - ground plants' parts.

\section{CONCLUSIONS}

1. The fertilizers brought into the soil (manure, sewage sludge and compost prepared from sewage sludge) as well as two levels of fertilizing had a significant influence on the yield of the seeds and straw of spring rape.

2. Manure, sewage sludge and compost prepared from sewage sludge did not have a larger influence on the decreasing or excessive increasing of heavy metals concentration in the seeds of spring rape. The double dose of fertilizers caused higher accumulation of heavy metals in the test plant.

3. The straw of spring rape should be treated as a source of organic matter and the main nutrients for soil. The highest concentration of copper, manganese, nickel and zinc in the straw of spring rape was noticed after an application of sewage sludge and of cadmium and lead after an application of compost prepared from sewage sludge.

4. The content of heavy metals in the plant material did not exceed permissible norms (with the exception of cadmium and lead) of usefulness of the product for consumption. 


\section{LITERATURE CITED}

(1) Rozporządzenie Ministra Środowiska z dnia 1 sierpnia 2002 r. w sprawie komunalnych osadów ściekowych. Dz U z 2002 r. nr 134, poz. 1140.

(2) Baran S., Szczepanowska I., Saadi L.: Wpływ użyźniania osadem ściekowym o różnym stopniu przetwarzania na zawartość form azotu w glebie lekkiej. Fol. Univ. Stetinensis, 200 Agricultura, 1999, (77)15 - 20.

(3) Czekała J.: Wartość próchnicotwórcza i działanie nawozowe osadu ściekowego. Fol. Univ. Stetinensis, 211 Agricultura, 2000, (84) $75-80$.

(4) Krzywy E., Wołoszyk Cz., Iżewska A.: Produkcja i rolnicze wykorzystanie kompostów $\mathrm{z}$ osadu ściekowego $\mathrm{z}$ dodatkiem różnych komponentów. Wydaw. PTIE, Oddział Szczeciński, 2002, 39.

(5) Rozporządzenie Ministra Zdrowia z dnia 31.03.1993, Monitor Pol. Nr 22/93.

(6) Kabata-Pendias A., Motowicka-Terelak T., Piotrowska M., Terelak H., Witek T.: Ocena stopnia zanieczyszczenia gleb i roślin metalami ciężkimi i siarką. Ramowe wytyczne dla rolnictwa. Wydaw. IUNG Puławy P, 1993, (53) 20.

(7) Baran S., Flis-Bujak M., Żukowska G., Kwiecień J., Pietrasik W., Kępczyński A.: Zmiany fizykochemicznych właściwości gleby lekkiej użyźnianej osadem ściekowym i wermikompostem. Zesz. Prob.. Post. Nauk Rol., 1998, 456, $515-523$.

(8) Mercik S., Kubik J.: Chelatowanie metali ciężkich przez kwasy humusowe oraz wpływ torfu na pobieranie $\mathrm{Zn}, \mathrm{Pb}$ i Cd przez rośliny. Zesz. Probl. Post. Nauk Rol., 1995, 422, 19 -30 .

(9) Filipek-Mazur B., Mazur K., Gondek K.: Zależność między pochodzeniem i terminem stosowania osadów ściekowych a plonowaniem kukurydzy i zawartością w niej metali ciężkich. Acta Agrophys., 2002, 70(1)127 - 136.

(10) Korboulewsky N., Bonin G., Massianic C.: Biological and ecophysiological reactions of white wall rocket grown on sewage sludge compost. Environ. Poll., 2002, 117(2) 365 -370 . 